\title{
Analysis Young Driver Behavior in Z Generation
}

\author{
Khusnul Khotimah ${ }^{1}$, Yogi Arisandi ${ }^{2}$ \\ ${ }^{I}$ Politeknik Transportasi Darat Indonesia-STTD, Cibitung No.9 Bekasi and Postcode, Indonesia \\ ${ }^{2}$ Balitbanghub, Merdeka Timur, Jakarta and Postcode, Indonesia
}

\section{ARTICLE INFO}

AIJ use only:

Received date : 05 June 2020

Revised date : 20 July 2020

Accepted date : 22 July 2020

Keywords:

Young Driver

Driver Behavior

"Z" Generation

\begin{abstract}
A B S T R A C T
The magnitude of the cause of the accident due to driver error causes the need to do an analysis related to the characteristics of the driver and the factors that most influence the cause of the accident and then the road. At this time the young driver is in $\mathrm{Z}$ generation who has an age between 16-21 years. An analysis of the characteristic causes of traffic accidents, especially in the "Z" generation of drivers by using the driver simulator "Teknosim" and the results of the analysis of observations through crosstab models and chi square test to the influential variable obtained that the characteristics of the generation driver " $\mathrm{Z}$ " in low traffic tends to move lane under the right conditions, brake suddenly with very minimal dexterity. It causes collisions with other vehicles with a very short reaction time without agility of 0.012 minutes, and even can improve how to drive and can not prevent wasteful consumption of fuel even in traffic that is not dense with Asymp. Sig values (2-sided) in the amount of 0.010 0.014. In heavy traffic conditions, the "Z" Generation driver has the characteristic of tapping the horn and tends to brake suddenly with a very small braking distance or too close to the vehicle in front of him and very minimal dexterity with the Asymp.Sig value. (2-sided) in the amount of $0.014-0.017$.
\end{abstract}

\section{INTRODUCTION}

World Health Organization (WHO) revealed 48 percent of victims who died were the productive ages (15-44 years). The traffic accident victims with high school education (SLA) occupy the most numbers. Data from the Indonesian Police Traffic Corps shows the percentage of victims with a high school education background reached 57 percent.

Supporting this research, as well as to find out the factors that most influence the characteristics of drivers at young age or more precisely in the "Z" generation, an observation survey was conducted on drivers who fall into that category, namely at the age of 16-21 years.

\footnotetext{
* Corresponding author.

E-mail address: khusnulmanisque31@gmail.com

Article with open access under license
}

\section{METHOD}

\section{Analysis Variabel}

The study was conducted with a basic hypothesis in which there are some differences in driving characteristics among $\mathrm{Z}$ Generation. The characteristics that will be observed as well as being dependent variables include the followings.

1. Reaction Time in seconds (s)

2. Measured as the interval between initial scenarios for the first indication of an acceptable response gap

3. Driving agility

4. Anticipation

5. Take Decisions as Conflict Reactions

6. Color Blindness 
7. The vision function of the driver in receiving information

8. The sequence of responses when dealing with various conflicts that are simulated

Meanwhile, the independent variables are needed to see the factors that cause the distinguishing characteristics of driving among $\mathrm{Z}$ Generation. Some of the suspected factors are:

1. Gender

2. Age

3. The range of time, the respondent can drive

4. Music genre used while driving

5. Hobbies in play games

6. Use of cellular phones when driving

\section{Instrument Collecting Data}

The Data Collection Equipment is a driving simulator. The driving simulator consists of a series of driver assessments of various simulated road environment situations and a data acquisition system of driving results. The driver section of the simulator consists of a car seat, steering wheel, dashboard and pedals.

The stimuli are in the form of a device with 3 monitor screens in the form of front view and rear view mirror situations, right side left and side mirrors. The simulator that will be used is the bus driving simulator at the Road Transportation and Road Transportation High School Laboratory, as shown in the following figure

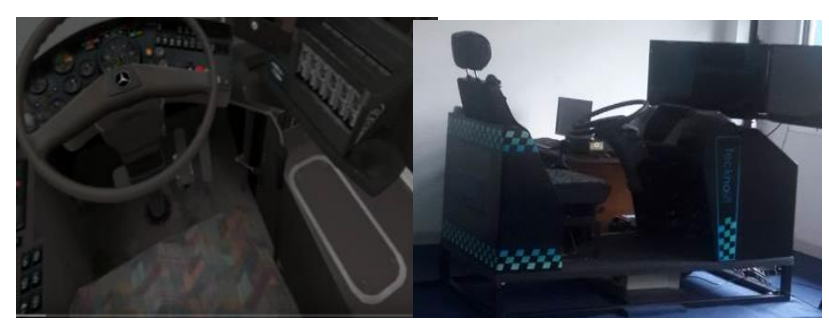

Picture 1. TeknoSim Bus Driving Simulator

\section{Analysis Method}

1. Cross Tab Analysis Method

Cross tab analysis method is carried out to find out the relationship between the independent variable and the dependent variable which is suspected to be the dominant cause of accident in generation $\mathrm{Z}^{*}$.
Observations made on STTD cadets as objects of research were carried out through 2 (two) stages, namely pre-observation in order to provide practical experience in recognizing the basics of the driving process and the second stage was observing by simulating various scenarios contained in the simulator module. The assessment of driving ability using a simulator produces several variables can be seen in the following table.

Table 1. Research Variables

\begin{tabular}{|c|c|c|}
\hline NO & $\begin{array}{c}\text { DEPENDENT } \\
\text { VARIABLES (Y) }\end{array}$ & $\begin{array}{c}\text { INDEPENDET } \\
\text { VARIABLES (X) }\end{array}$ \\
\hline 1 & Turn without indicators & Reaction time \\
\hline 2 & Moving lane is incorrect & Dexterity \\
\hline 3 & Violation of signs & Anticipation \\
\hline 4 & Too fast & Decision-making \\
\hline 5 & $\begin{array}{c}\text { Stop in a restricted parking } \\
\text { area }\end{array}$ & Color blind \\
\hline 6 & Driving in the wrong lane & Vision \\
\hline 7 & Cross the yellow line & \\
\hline 8 & Stop line violations & \\
\hline 9 & Violation honking & \\
\multicolumn{3}{|c|}{ Sumber: Analysis References 2020 }
\end{tabular}

\section{Chi Square Analysis Method}

The analysis was carried out in identifying the relationship between independent and bound variables using the cross tab analysis method and then testing the statistical data using the chi-square method to determine the ratio of the relationship between these variables. The analysis was performed using statistical data processing software aids with a confidence level of $95 \%$ or $\alpha=0.05$ whose results will be described as follows. The hypothesis of this research is.

H0 : there is no influence between the independent variables (clinical characteristics of the driver) with the dependent variable (stimuli driving behavior using a simulator)

$\mathrm{H} 1$ : there is influence between independent variables (clinical characteristics of the driver) with the dependent variable (stimuli driving behavior using a simulator) 


\section{RESULTS AND DISCUSSION}

\section{Scenario 1 (Eco* / Smart Drive in Urban Conditions with Low Traffic)}

The first scenario is the observation of the object of study in driving by using the Eco/Smart Drive function in urban conditions with low traffic.

Relationship Between Variable Driver Clinical Characteristics With Traffic Violation Variables in Scenario 1

Table 2. Relationship Between Variable Driver Clinical Characteristics With Traffic Violation Variables in Scenario 1

\begin{tabular}{|l|c|c|c|}
\hline & $\begin{array}{c}\text { Reaction } \\
\text { time } \\
(\mathrm{X} 1)\end{array}$ & $\begin{array}{c}\text { Dexterity } \\
(\mathrm{X} 2)\end{array}$ & $\begin{array}{c}\text { Anticipation } \\
(\mathrm{X} 3)\end{array}$ \\
\hline Turn without indicators & 0,043 & 0,075 & 0,084 \\
\hline Moving lane is incorrect & 0,023 & 0,015 & 0,035 \\
\hline Violation of signs & 0,016 & 0,047 & 0,27 \\
\hline Too fast & 0,045 & 0,039 & 0,027 \\
\hline $\begin{array}{l}\text { Stop in a restricted parking } \\
\text { area }\end{array}$ & 0,38 & 0,025 & 0,01 \\
\hline Driving in the wrong lane & 0,94 & 0,016 & 0,04 \\
\hline Cross the yellow line & 0,011 & 0,041 & 0,017 \\
\hline Stop line violations & 0,19 & 0,72 & 0,04 \\
\hline Violation honking & 0,037 & 0,56 & 0,021 \\
\hline
\end{tabular}

\begin{tabular}{|l|c|c|c|}
\hline & $\begin{array}{c}\text { Decision- } \\
\text { making } \\
(\mathrm{X} 4)\end{array}$ & $\begin{array}{c}\text { Color } \\
\text { blind } \\
(\mathrm{X} 5)\end{array}$ & Vision (X6) \\
\hline Turn without indicators & 0,012 & 0,57 & 0,12 \\
\hline Moving lane is incorrect & 0,012 & 0,14 & 0,67 \\
\hline Violation of signs & 0,034 & 0,012 & 0,025 \\
\hline Too fast & 0,017 & 0,36 & 0,089 \\
\hline $\begin{array}{l}\text { Stop in a restricted parking } \\
\text { area }\end{array}$ & 0,013 & 0,077 & 0,23 \\
\hline Driving in the wrong lane & 0,021 & 0,044 & 0,027 \\
\hline Cross the yellow line & 0,37 & 0,036 & 0,012 \\
\hline Stop line violations & 0,018 & 0,022 & 0,028 \\
\hline Violation honking & 0,039 & 0,085 & 0,16 \\
\hline
\end{tabular}

Based on the statistical test results using the Chi-Square test method, the strongest relationship between independent variables and dependent variables is indicated by the Asymp.Sig value. (2sided) $\leq \alpha=0.05$, that is, between the Decision Making variable (Y) and the Inappropriate Moving Line (X) variable with the Asymp.Sig value. (2sided) 0.01 .

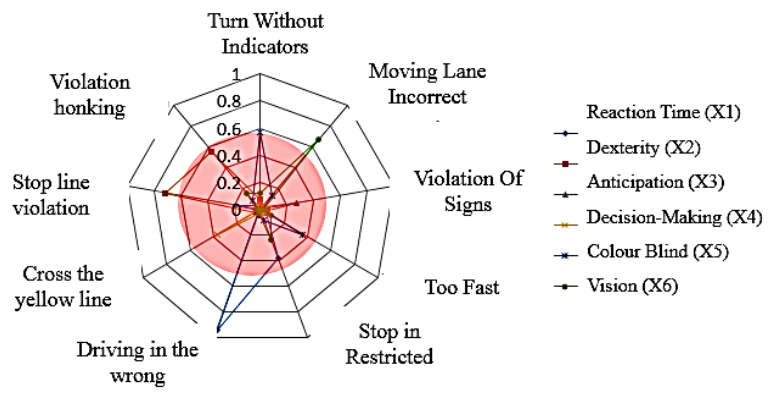

Picture 2. Radar Diagram of Relationship Between Variable Clinical Characteristics of Drivers with Traffic Violation Variables in Scenario 1

Based on the statistical test results using the Chi-Square test method, the strongest relationship between independent variables and dependent variables is indicated by the Asymp.Sig value. (2sided) $\leq \alpha=0.05$, that is, between the Sudden Braking variable $(\mathrm{Y})$ and the Agility variable (X) with the Asymp.Sig value. (2-sided) 0.014

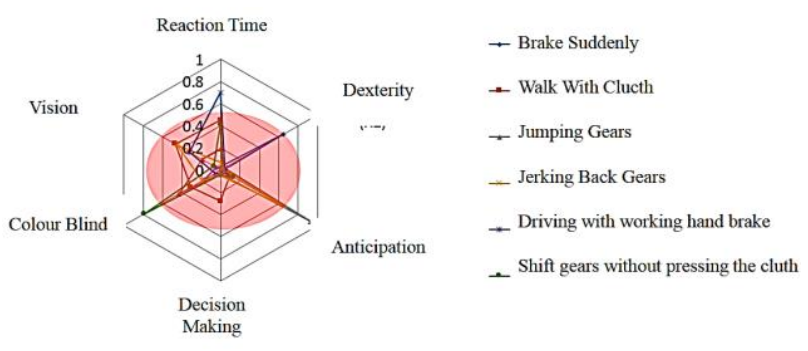

Picture 3. Radar Diagram of Relationship Between Variable Clinical Characteristics of Drivers with Driving Violation Variables in Scenario 1

Based on the statistical test results using the Chi-Square test method, the strongest relationship between independent variables and dependent variables is indicated by the Asymp.Sig value. (2sided) $\leq \alpha=0.05$, namely between the Collision variable with Other Vehicles (Y) and the Reaction Time variable $(\mathrm{X})$ with the Asymp.Sig value. (2sided) 0.012 .

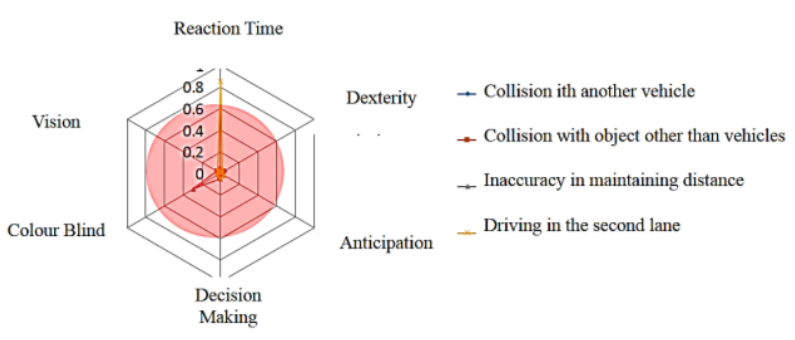

Picture 4. Radar Diagram of Relationship Between Clinical Characteristics of Drivers with Defensive Driving Violence Variables in Scenario 1

* Eco

How to drive that aims to optimize fuel consumption efficiently and play a role in reducing the risk of accidents on the highway 


\section{Scenario 2 (Eco / Smart Drive in Urban Conditions with Heavy Traffic)}

The second scenario is the observation of study objects in driving by using the Eco/Smart Drive function in urban conditions with heavy traffic.

Table 3. Relationships Between Variable Clinical Characteristics of Drivers With Traffic Violation Variables in Scenario 2

\begin{tabular}{|c|c|c|c|}
\hline & $\begin{array}{c}\text { Reaction } \\
\text { time } \\
(\mathrm{X} 1)\end{array}$ & $\begin{array}{c}\text { Dexterity } \\
(\mathrm{X} 2)\end{array}$ & $\begin{array}{c}\text { Anticipation } \\
(\mathrm{X} 3)\end{array}$ \\
\hline Turn without indicators & 0,021 & 0,135 & 0,072 \\
\hline Moving lane is incorrect & 0,037 & 0,055 & 0,019 \\
\hline Violation of signs & 0,027 & 0,038 & 0,41 \\
\hline Too fast & 0,048 & 0,042 & 0,038 \\
\hline Stop in a restricted parking & 0,57 & 0,021 & 0,07 \\
\hline Driving in the wrong lane & 0,85 & 0,013 & 0,052 \\
\hline Cross the yellow line & 0,006 & 0,028 & 0,009 \\
\hline Stop line violations & 0,25 & 0,54 & 0,059 \\
\hline Violation honking & 0,025 & 0,21 & 0,017 \\
\hline
\end{tabular}

\begin{tabular}{|c|c|c|c|}
\hline & $\begin{array}{c}\text { Decision- } \\
\text { making } \\
(\mathrm{X} 4)\end{array}$ & $\begin{array}{c}\text { Color } \\
\text { blind } \\
(\mathrm{X} 5)\end{array}$ & Vision (X6) \\
\hline Turn without indicators & 0,008 & 0,78 & 0,39 \\
\hline Moving lane is incorrect & 0,035 & 0,09 & 0,49 \\
\hline Violation of signs & 0,072 & 0,049 & 0,031 \\
\hline Too fast & 0,028 & 0,73 & 0,26 \\
\hline Stop in a restricted parking & 0,045 & 0,038 & 0,4 \\
\hline area & 0,016 & 0,048 & 0,039 \\
\hline Criving in the wrong lane & 0,45 & 0,041 & 0,008 \\
\hline Stop line violations & 0,027 & 0,047 & 0,037 \\
\hline Violation honking & 0,014 & 0,059 & 0,09 \\
\hline
\end{tabular}

Source:Analysis Result Of 2020

It can be seen in the table above that the strongest relationship between the independent variable and the dependent variable is indicated by the Asymp.Sig value. (2-sided) $\leq \alpha=0.05$, that is, between the Collision variable and Horn Violation Violation (Y) and the Decision Making variable (X) with the Asymp.Sig value. (2-sided) 0.014.

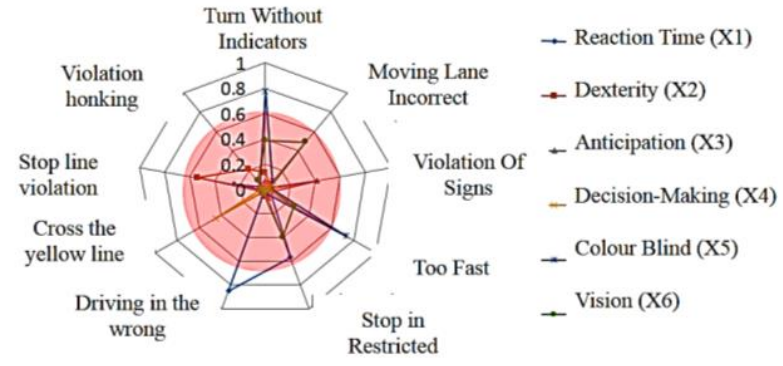

Picture 5. Radar Diagram of Relationship Between Variable Clinical Characteristics of Drivers with Traffic Violation Variables in Scenario 2

It can be seen in the following figure that the strongest relationship is between the independent variable and the dependent variable shown by the Asymp.Sig value. (2-sided) $\leq \alpha=0.05$, that is, between the collision variable with sudden braking (Y) and the anticipation variable (X) with an Asymp.Sig value. (2-sided) 0.011 .

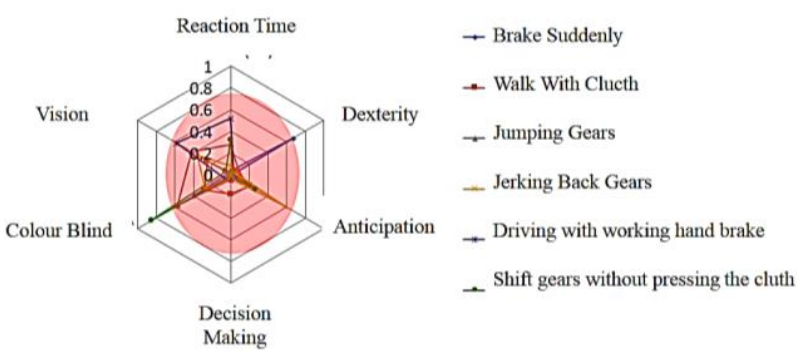

Picture 6. Radar Diagram of Relationship Between Variable Clinical Characteristics of Drivers with Driving Violation Variables in Scenario 2

Based on the test results statistically using the Chi-Square test method the strongest relationship between the independent variable with the dependent variable indicated by the Asymp.Sig value. (2-sided) $\leq \alpha=0.05$, that is, between Inaccuracy Maintaining Distance (Y) and Agility variable (X) with Asymp.Sig values. (2-sided) 0.017 . 


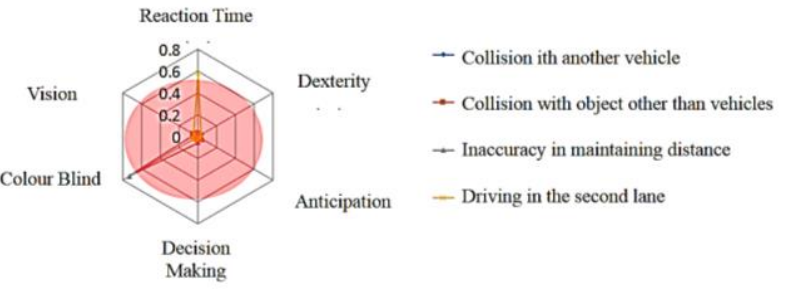

Picture 7. Radar Diagram of Relationship Between Variable Clinical Characteristics of Drivers with Defensive Driving Violence Variables in Scenario 2

\section{CONCLUSION}

The characteristics of the Stimuli of "Z" Generation most dominant causes of accidents descriptively from the simulator test results are as follows.

1. In the condition of Eco/Smart Drive for very quiet or low traffic that the "Z" Generation driver has the following characteristics:

a. Tend to move lane in conditions that are not right with the value of Asymp.Sig. (2-sided) 0.01 .

b. Tend to brake suddenly with very minimal dexterity with Asymp.Sig value. (2-sided) 0.014

c. Ponit $\mathrm{a}$ and $\mathrm{b}$ cause a tendency to collide with other vehicles with a very short reaction time without agility of 0.012 minutes with an Asymp.Sig value. (2-sided) 0.012 .

d. have not been able to improve how to drive and have not been able to prevent wasteful consumption of fuel even in non-congested traffic

2. In the condition of Eco/Smart Drive for heavy or high traffic that the "Z" Generation driver has the following characteristics:

a. Tends to honk with Asymp.Sig value. (2sided) 0.014

b. Tend to brake suddenly with a very small braking distance or too close to the vehicle in front of him and very minimal dexterity with the value of Asymp.Sig. (2-sided) 0.017

\section{REFERENCES}

,2008, Human Factors For Transport Safety Investigators, Kementrian Perhubungan Darat, Jakarta
,2009,Undang-undang Nomor 22 Tahun

2009 Tentang Lalu Lintas dan Angkutan Jalan, Direktorat Jenderal Perhubungan Darat, Jakarta

Barnard, Yvonne, etc, The Safety Of Intelligent Driver Support Systems, Ashgate Publishing Company, USA

Elvik, Rune, etc, 2009, The Handbook Of Road Safety Measures Second Edition, Emerald Group Publishing Company

J. Supranto , 2000,Teori dan Aplikasi

Statistik, Erlangga, Jakarta

Notoadmodjo, 2007, Teori Keperilakuan

Dalam Pengambilan Keputusan, Erlangga, Jakarta

Suartana, I Wayan, 2010, Konsep Teori

Keperilakuan Transportasi, Andi, Yogyakarta

OECD, 2003, Road Safety Impact Of New

Technologies, Securite Routiere, OECD Publishing Company

OECD, 2006, Young Drivers The Road To Safety, European Conference Of Ministers of Transport

Wibisono, Yusuf, 2005, Metode Statistik, Erlangga, Jakarta

http://www.4muda.com/mengenalgenerasi-x-y-dan-z-sebagai-generasi-dominanmasa-kini/

White, James. Meet Generation Z: Understanding and Reaching the New PostChristian World. Kindle

Li Shuguang, dkk.(2014). Learning Characteristic Driving Operations in Curve Section that Reflect Drivers'Skill Levels. Vol.2 No.3 International Journal of Intelligent Transportation Systems Research

Wang M, dkk (2018). Analysis of Driver's Characteristic Driving Operations Based on Combined Features. Vol.1 Issue 3. Journal of Intelligent and Connected Vehicles ISSN: 19471017. School of Manufacturing Science and Engineering, Sichuan University 